\title{
THE IMPACTS OF FINANCING INVESTMENT SCENARIOS ON PIPED-NATURAL GAS PRICES (GPS) FOR HOUSEHOLDS IN INDONESIA
}

\author{
Aji Agraning Bawono ${ }^{1 *}$, Eny Kusrini ${ }^{1}$ \\ ${ }^{1}$ Department of Chemical Engineering, Faculty of Engineering, Universitas Indonesia, Kampus UI \\ Depok, Depok 16424, Indonesia
}

(Received: March 2017 / Revised: May 2017 / Accepted: December 2017)

\begin{abstract}
The objective of this study was to compare the impacts of financing investment scenarios on piped-natural GPs for households in Indonesia using government, business entity, and mixed investment scenarios. Simulations of cash flow were used for a case study of domestic GPs in City X in Indonesia, which originally used only one investment scheme. The GPs is calculated using the cash flow (CF) method. With the cash flow, GPs is calculated based on the sum of investment costs (Capital Expenditure), operating and maintenance costs ( $O \& M)$, gas purchase costs, administrative costs $(\mathrm{A})$, tax $(\mathrm{t})$, and margin $(\mathrm{m})$ divided by gas volume. A sensitivity test was performed using the models to observe the effects of changes to each component of each variable regarding price calculations for natural gas. The government divided the type of household into two, one class consisting of simple house and small house and the second group consists of luxury homes, apartments, and condominiums. For $100 \%$ government investment scenarios, prices were formulated using management fee systems. For $100 \%$ business entity investment scenarios, prices were formulated with a method in which an internal rate of return (IRR) equaled a weighted average cost of capital (WACC). For mixed government and business entity investment scenarios, prices were derived by modifying $100 \%$ government investment scenarios calculations. A study of setting piped-natural GPs for households that are equitable, fair, transparent, and able to meet citizens' purchasing powers was then conducted. Using the calculations and simulations, it was concluded that the government investment scenarios provided the lowest GPs but burdened the state budget. The business investment scenarios provided high GPs and benefitted the firm but not the community. The mixed investment scenario with 50:50 government and business entity investment composition was recommended for setting GPs; they increased investments and public welfare, could be just and fair, and could meet citizens' purchasing powers.
\end{abstract}

Keywords: Business entity; Government; Household gas price; Mixed investment; Natural gas; Pipeline

\section{INTRODUCTION}

Indonesia's oil reserves and declining oil production are the focus of the Indonesian government, which aims to quickly change to and accelerate the use of a mixed-energy policy. Using natural gas as a substitute for petroleum not only has many economical, technological, and environmental advantages, but also improves efficiency because it can be developed easily (Lee et al., 2012; Gong et al., 2015). Thus, the Indonesian government developed a strategy to

*Corresponding author's email: abawono86@gmail.com, Tel: +62-21-7863516, ext. 204. Fax: +62-21-7863515

Permalink/DOI: https://doi.org/10.14716/ijtech.v8i8.982 
end the use of petroleum; one of the steps of the strategy is to increase the use of natural gas by households and small-scale consumers. The program is called the City Gas Program. With it, citizens can use fuel that is cleaner, safer, and cheaper than petroleum (Ministry of Energy and Mineral Resources of the Republic of Indonesia, 2013).

Every country in the world has piped-gas regulations related to prices and tariffs. In developed countries, such as countries in Europe and North America, GPs are regulated based on market prices, and governments are not involved they are just facilitators (International Gas Union, 2017). In developing countries, such as Indonesia, regulated price systems are adopted with which GPs are regulated by governments, who set the GPs. On a study of household gas prices conducted in Iran, subsidies are used with the aim of providing low GPs to the public, although the low prices burden state budgets, which must be in line increased energy demands and rising energy prices (Moshiri, 2015). Governments that intervene with GPs usually aim to not only make gas prices fair for employers but also pay attention to citizens' purchasing powers (International Gas Union, 2017).

In Indonesia, the prices of gas for households are based on a government-financing scenario (Ministry of Energy and Mineral Resources of the Republic of Indonesia, 2013). Gas infrastructure can be funded by $100 \%$ government (G), $100 \%$ business entitiy (B) or mixed (M) investments (PwC Indonesia, 2016). In the future, most gas infrastructure is developed using fully business entity and mixed investments. A model of GPs using various investment scenarios is needed to consider the impact of each funding scenario on changes in GPs (The Oil and Gas Downstream Regulatory Agency of the Republic of Indonesia, 2011). The objective of this study was to compare the impacts of various financing scenarios on piped-natural GPs for households in Indonesia; the different investment scenarios that were tested were government, business entity, and mixed. Finally, the best investment scenario from this study can be recommended for determination the households gas price (GPs) in Indonesia.

\section{METHODS}

This study's gas-price calculation model for households was used for a case study of GPs in City $\mathrm{X}$ in Indonesia. The GPs is calculated using the cash flow (CF) method. With the cash flow, GPs is calculated based on the sum of investment costs (Capital Expenditure), operating and maintenance costs $(\mathrm{O} \& \mathrm{M})$, gas purchase costs, administrative costs $(\mathrm{A})$, tax $(\mathrm{t})$, and margin (m) divided by gas volume. Besides calculating GPs, cash flow method can be used to know investment and economic parameters such as calculating IRR. GPs were first calculated with a $100 \%$ government investment scenario. The prices were then recalculated with other investment scenarios (i.e., with 100\% business entity and mixed 50\% business-and-50\% government investment scenarios).

The GPs are divided into two categories based on the purchasing powers of consumers. Household type one (H1) includes simple houses, and very simple houses. Household type two (H2) includes medium homes, luxury homes, and apartments. GPs for household two (H2) are equal to the lowest GPs for household one and are as much as 100\% more than the GPs for household one (The Oil and Gas Downstream Regulatory Agency of the Republic of Indonesia, 2011). After calculation results were obtained, multiple sensitivity tests were conducted, and some changes were made to various parameters, such as the composition of capital and the proportion of funding from the government and a business.

\subsection{A $\mathbf{1 0 0 \%}$ Government Investment Scenario}

When-natural gas infrastructure is $100 \%$ financed by a government, the cost of investment, or capital expenditure (CAPEX), is zero in regards to natural GPs for households (The Oil and Gas Downstream Regulatory Agency of the Republic of Indonesia, 2011). The government provides 
an incentive to the public in that citizens do not have to pay the CAPEX. The investment cost of pipeline construction by a gas-pipeline operator is paid by the government as a subsidy so that the cost does not need to be returned to the operator and the community. Therefore, the GPs includes the purchase cost of upstream natural gas, operating and maintenance expenses, general and administrative expenses, taxes, regional debts, income, and a reasonable profit margin determined by the regulator (Purwanto \& Sommeng, 2013).

When establishing a profit margin, the regulator, i.e., the government, considers the profits of companies, citizens' purchasing powers, and current regulations, which are divided by the volume of gas supplied per $\mathrm{m}^{3}$ (Oil and Gas Downstream Regulatory Agency of the Republic of Indonesia, 2011).

For City X, the equation for $100 \%$ government investments was

$$
\text { Gas price }=\frac{P+O+A+t+m}{V}
$$

where $P$ was the gas purchase cost, including losses and toll fees, $O$ was operating and maintenance costs, $A$ was general and administration fees, $t$ was taxes, $m$ was a reasonable (i.e., affordable) margin, and $V$ was the gas's volume in cubic meters $\left(\mathrm{m}^{3}\right)$.

The calculation result of piped-natural GPs in City X using investment scenarios from $100 \%$ government for household one (GH1) can be seen in Figure 1, while for household two (GH2) can be seen in Figure 2.

\subsection{A $100 \%$ Business Entity Investment Scenario}

Some businesses' activities include providing public utilities, such as electricity, telephone, and water. Natural-gas pipeline infrastructure is often a public-infrastructure business activity, or public utility. The capital budgeting approach of a company that provides public infrastructure is rather different from that of an ordinary business, in general. Gain (i.e., income) from the company's public utilities is regulated, which is unusual for enterprises (Hunt, 2014). Regular projects, such as investment projects in general, will be executed by a company if the IRR exceeds the cost of capital and will be refused if the IRR is below the cost of capital. Therefore, the company will seek to obtain the highest possible IRR for all products sold on a market to gain as much income as possible (Brigham \& Pettway, 1973).

According to the theory of traditional regulation, the existence of such regulatory mechanisms eliminates the producer's surplus (an IRR above the zone of reasonableness). If the excess is reduced by regulatory action, then the project has a net present value (NPV) equal to zero, or the IRR is equal to the cost of capital (Murray \& Frank, 2015). Thus, selecting projects to maximize the NPV cannot be performed for public-infrastructure business activities - at least under the theory of traditional regulation (Brigham \& Pettway, 1973; Brigham \& Pettway, 2009).

Regulators, or governments of countries, generally determine the maximum limit of the zone of reasonableness (the IRR) based on the cost of capital or the WACC used to fund related publicinfrastructure projects (Tapia, 2010; Weijermars, 2011; Federal Energy Regulatory Commission, 1999; Hunt, 2014). Therefore, when determining rates or prices of public infrastructure, discount rates used in free cash flow (FCF) are equal to WACCs. WACC reflects a business's cost of debt (CoD) and cost of equity (CoE) (Miller, 2006; Axel, 2009).

The cost of debt is interest expense that must be paid by the company to a creditor, and the cost of equity is a dividend that must be paid by the firm to its shareholders. WACC is the weighted average cost of funding assets derived from loan creditors (debt) and funds from shareholders 
(equity), and the percentage of usage determines the weights of each. By knowing the WACC, how much interest a company must pay for every dollar of money invested can be known. Therefore, when evaluating the feasibility of a project, the WACC is the appropriate discount rate used for the analysis of the business's cash flow (Brigham \& Pettway, 1973; Murray and Frank, 2015).

For this study, WACC was mathematically formulated as

$$
W A C C=C o E \frac{E}{E+D}+C o D \frac{D}{E+D}
$$

where $E$ was equity and $D$ was debt. $\mathrm{CoE}$ and $\mathrm{CoD}$ were calculated using

$$
C o E=R f+\beta(I C R P+B P M E M)
$$

and

$$
C o D=i \times(1-t)
$$

where $R f$ was the risk-free rate of a United States (US) treasury bond, beta ( $\beta$ was a measure of an investment portfolio fluctuation compared to a measure of a Indonesian stock market, ICRP was Indonesia's country risk premium, BPMEM was a based premium for mature equity market country in the world, and $I$ was an interest rate. However, the coe calculation equation above uses the us dollar parameter (USD), so the CoE needed to be modified for the Indonesian parameter $\left(\mathrm{CoE}_{\mathrm{IDN}}\right)$ by adding local inflation and the inflation of the USD. Thus, the calculation of the CoE used the equations (Damodaran, 2012; Damodaran, 2013).

$$
\operatorname{CoE}_{I D N}=\left[\frac{\left(1+\operatorname{CoE}_{\text {in } U S D}\right) *(1+\text { Local inflation })}{(1+U S D \text { inflation })}\right]-1
$$

and

$$
C o E_{I D N}=\left[\frac{(1+R f+\beta(B P M E M+I C R P) *(1+\text { Local inflation })}{(1+U S D \text { inflation })}\right]-1
$$

After the WACC was calculated, it was used as a target IRR to calculate natural GPs for households using FCF by inserting an additional component, depreciation costs, as CAPEX with the equations.

$$
\text { Gas price }=\frac{P+d+O+A+t+m}{V}
$$

and

$$
I R R=W A C C
$$

where $d$ was depreciation (IDR).

\subsection{A Mixed Government and Business Investment Scenario}

The calculation of natural GPs for City X's households with a mixed government and business investment scenario used the same method as the calculation of natural GPs for households with 
a $100 \%$ business investment scenario. The only difference was related to the CAPEX; the CAPEX was estimated using only the depreciation expenses of a portion of the business's investment; the government's CAPEX was zero. Thus, the equation

$$
\text { Gas } \text { price }=\sum_{i}^{t}\left(\frac{P_{m i x}+d_{m i x}+O_{m i x}+A_{m i x}+t_{m i x}+m_{m i x}}{V_{m i x}}\right)_{i}
$$

was used. $P_{\text {mix }}$ was the cost of gas purchases after a natural-gas pipeline development, including losses and tariffs, $d_{m i x}$ was depreciation costs, or the CAPEX of the business, and $O_{m i x}$ was operating and maintenance costs after the development. $A_{\text {mix }}$ was general and administrative costs after the development, $T_{m i x}$ was the corporate income tax after the development, $M_{m i x}$ was the reasonable profit margin after the development, and $V_{\text {mix }}$ was the volume of the natural gas after the development $\left(\mathrm{m}^{3}\right)$.

The Simulation of GPs with mixed investment scenario is calculated by making comparisons for various government investment compositions from $0 \%$ to $90 \%$ to see changes in gas prices due to changes in the amount of investment composition from government in a mixed scenario. The calculation results can be seen in Figure 9.

The calculation result of of piped-natural GPs for household one in City X with a 50:50 mixed ratio of business entity to government investment and $100 \%$ equity $(\mathrm{M} 1 \mathrm{H} 1)$ and $70 \%$ debt (M2H1) can be seen in Figure 1, while for household two with a 50:50 mixed ratio of business to government investment and $100 \%$ equity (M2H2) and $70 \%$ debt $(\mathrm{M} 2 \mathrm{H} 2)$ can be seen in Figure 2.

In this study also made a comparison of domestic gas prices 1 and 2 with liquified petroleum gas (LPG) price. LPG is the primary fuel household in Indonesia. The price of household gas 1 compared to LPG $3 \mathrm{~kg}$ size for middle to lower class while the price of household gas 2 with LPG $12 \mathrm{~kg}$ for upper middle class. The purpose of this comparison is to know the ratio of household gas that is transported through a pipe with LPG gas packed in a tube. household gas through pipelines is expected to replace LPG originating from imports and limited availability in Indonesia (Ministry of Energy and Mineral Resources of the Republic of Indonesia, 2017).

\section{RESULTS AND DISCUSSION}

The simulation results of the calculation of natural GPs for household types one and two using various investment scenarios can be seen in Figures 1 and 2. Based on the simulation results of the calculations in Figures 1 and 2, it was seen that the GPs for the households using 100\% government investments ( $\mathrm{GH} 1$ and $\mathrm{GH} 2$ ) were the lowest compared to the GPs for the households using either $100 \%$ business entity investments $(\mathrm{B} 1 \mathrm{H} 1, \mathrm{~B} 1 \mathrm{H} 2, \mathrm{~B} 2 \mathrm{H} 1$, and $\mathrm{B} 2 \mathrm{H} 2)$ or mixed investments $(\mathrm{M} 1 \mathrm{H} 1, \mathrm{M} 1 \mathrm{H} 2, \mathrm{M} 2 \mathrm{H} 1$, and $\mathrm{M} 2 \mathrm{H} 2)$. The prices were very reasonable because government investments do not include a CAPEX. CAPEXs were not passed to the community and were considered a subsidy from the government to reduce prices.

The highest gas price is produced from $100 \%$ investment scenario from business entity. It happens because the CAPEX of a business entity is incorporated into the price-forming component. Although reasonable margin has been set up by the regulator with the principle of $\mathrm{IRR}=\mathrm{WACC}$, it is still produced prices that are still high .

In Figures 1 and 2, the price of household gas from 100\% of government investment is always lower when compared with LPG price so that will become the attraction of the people switch to the gas pipeline. Although the price of household gas derived from $100 \%$ of the business and mixed investment is higher than LPG price, in accordance with Equation 9 in line with the 
increasing volume of pipe gas consumption, the price of household gas will become cheaper. The small amount of LPG due to imported goods compared to the abundant amount of household gas as methane gas in Indonesia will encourage the government to develop household gas as the primary fuel in the future (Ministry of Energy and Mineral Resources of the Republic of Indonesia, 2013).

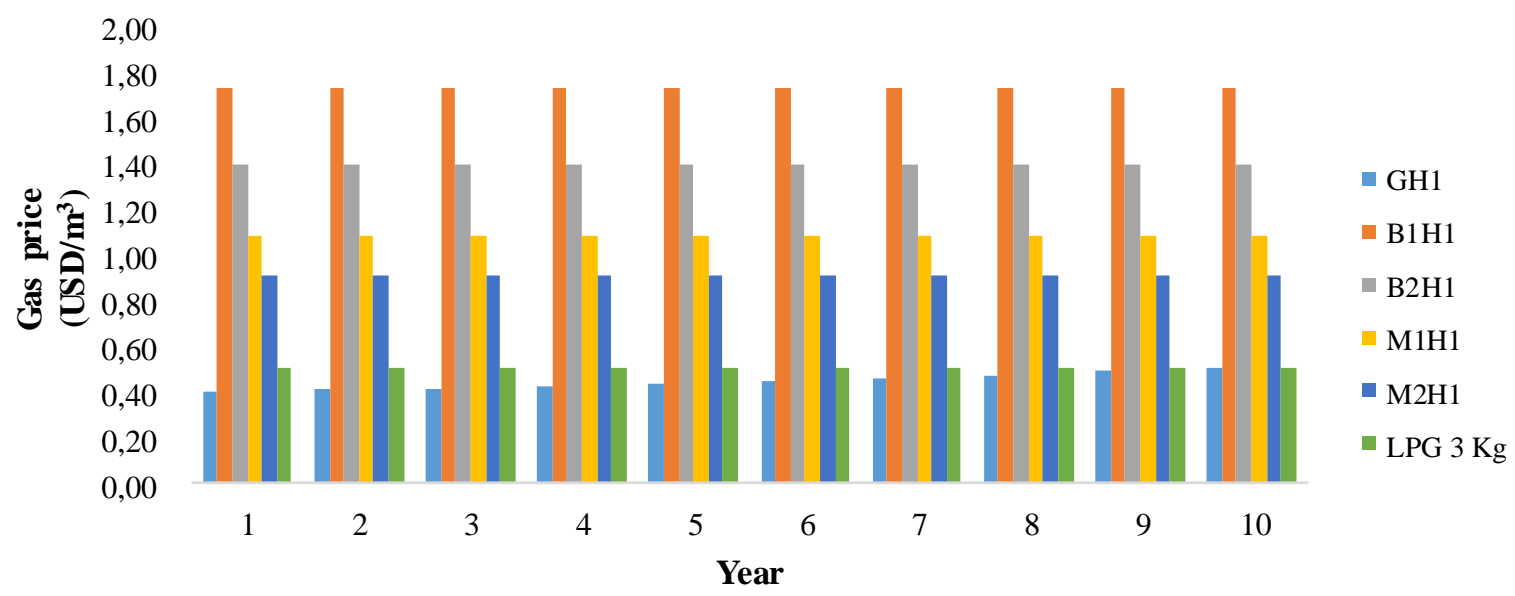

Figure 1 A comparison of piped natural GPs for household type one in City X that were determined using various investment scenarios, Where GH1 is GPs for the households type 1 with 100\% government investments, B1H1 is GPs for the households 1 using either $100 \%$ business entity investments with $100 \%$ equity, B2H1 is GPs for the households 1 using either $100 \%$ business entity investments with $100 \%$ with debt $70 \%$, M1H1 is GPs with mixed invesment for household type 1 with $100 \%$ equity, M2H1 is GPs with mixed invesment for household type 1 with $70 \%$ debt, and LPG $3 \mathrm{~kg}$ is liquified petroleum gas (LPG) price with tube size $3 \mathrm{~kg}$

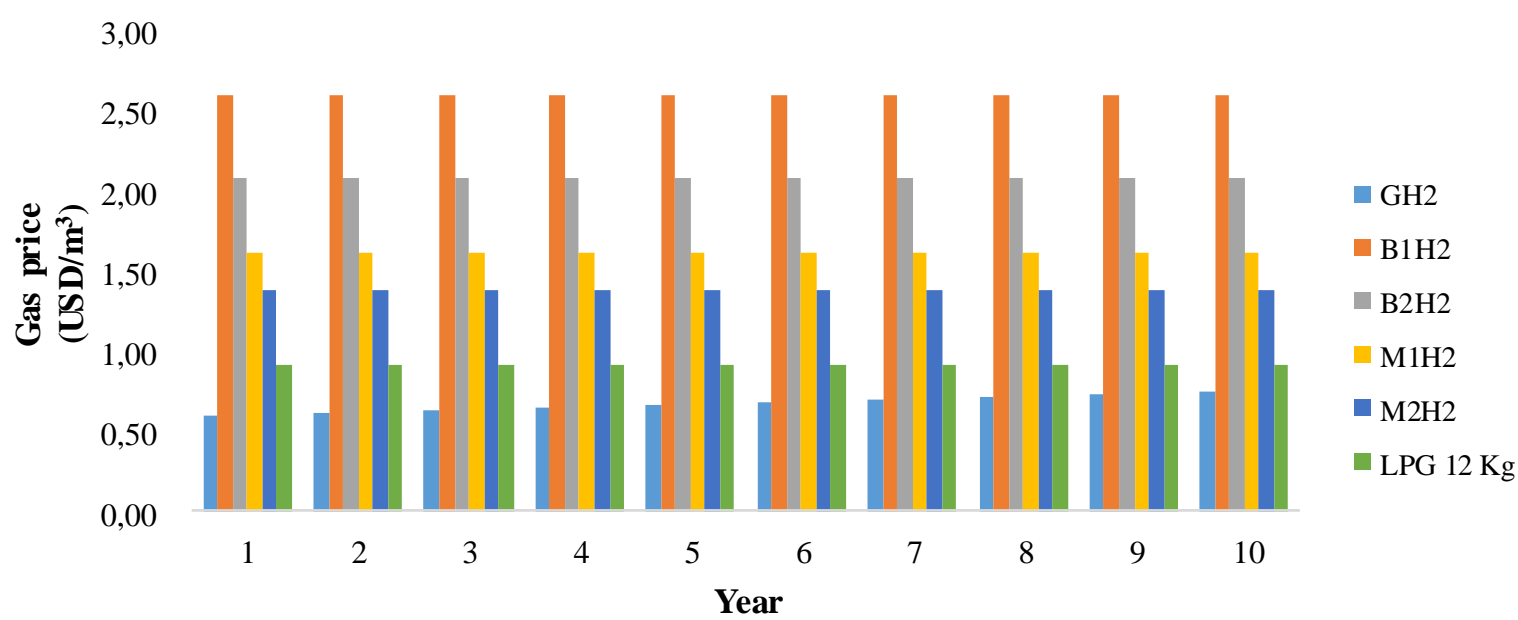

Figure 2 A comparison of piped-natural GPs for household type two in City X that were determined using various investment scenarios, Where GH2 is GPs for the households type 2 with $100 \%$ government investments, $\mathrm{B} 1 \mathrm{H} 2$ is GPs for the households 2 using either $100 \%$ business entity investments with $100 \%$ equity, B2H2 is GPs for the households 1 using either $100 \%$ business entity investments with $100 \%$ with debt $70 \%, \mathrm{M} 1 \mathrm{H} 2$ is GPs with mixed invesment for household type 1 with $100 \%$ equity, M2H2 is GPs with mixed invesment for household type 1 with $70 \%$ debt, and LPG $12 \mathrm{~kg}$ is liquefied petroleum gas (LPG) price with tube size $12 \mathrm{~kg}$.

CAPEX is the most significant component in forming GPs for $100 \%$ investment from business entities. If in a $100 \%$ government investment scenario the value of CAPEX is zero, then in the investment scenario $100 \%$ business entity is worth up to $49 \%$. Price forming component 
through investment scenario $100 \%$ business entity can be seen in Figure 3, while the comparison of gas price for household type 1 (BH1) and household type 2 (BH2) at different equity can be seen in Figure 4.

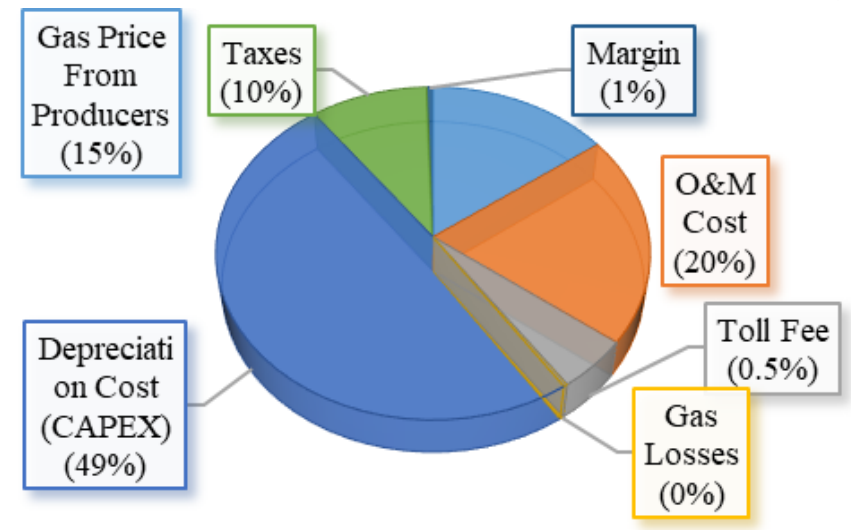

Figure 3 The components of GPs with $100 \%$ business entity investments.

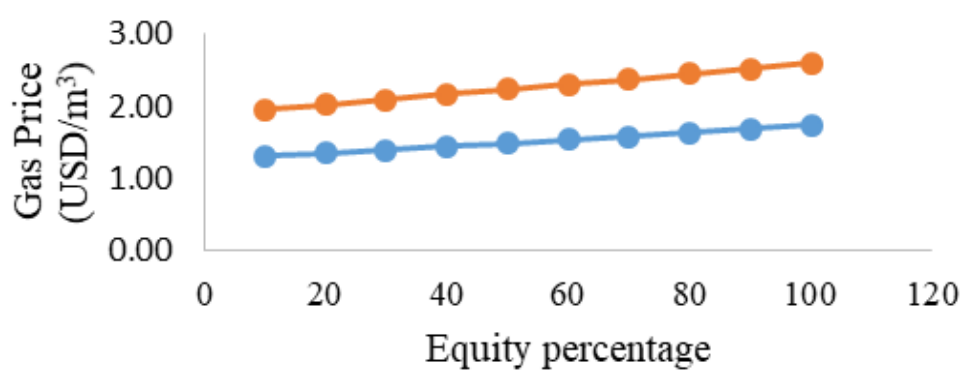

$(\%)$

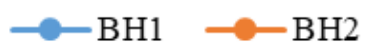

Figure 4 A comparison of household with $100 \%$ business entity investments. GPs with $100 \%$ business entity invesment on various percentages of equity, where BH1 is GPs with $100 \%$ business entity invesment for household type 1 and $\mathrm{BH} 2$ is GPs for household type 2

It is proposed that the construction of gas pipeline infrastructure as a joint investment between the government and a business be used to provide a balance between the government, the enterprise, and society. First, the development should be initiated by funding from the government as an incentive. Then, the infrastructure should be handed to a business entity. The purpose of mixing investment between business entities with the government is to reduce the value of CAPEX. The overall CAPEX value for gas infrastructure development will decline as it is subsidized by the government. Business entities only partially burdened a portion of it so that the gas price will decrease compared to the gas infrastructure built with $100 \%$ of business entities investment. This condition can be seen in Figure 5 where the value of CAPEX in the same infrastructure development previously decreased from $49 \%$ to $33 \%$ if CAPEX is a 50:50 mixed investment from government and business entities. The comparison of gas prices with a 50:50 mixed investment in various equity changes can be seen in Figure 6. 


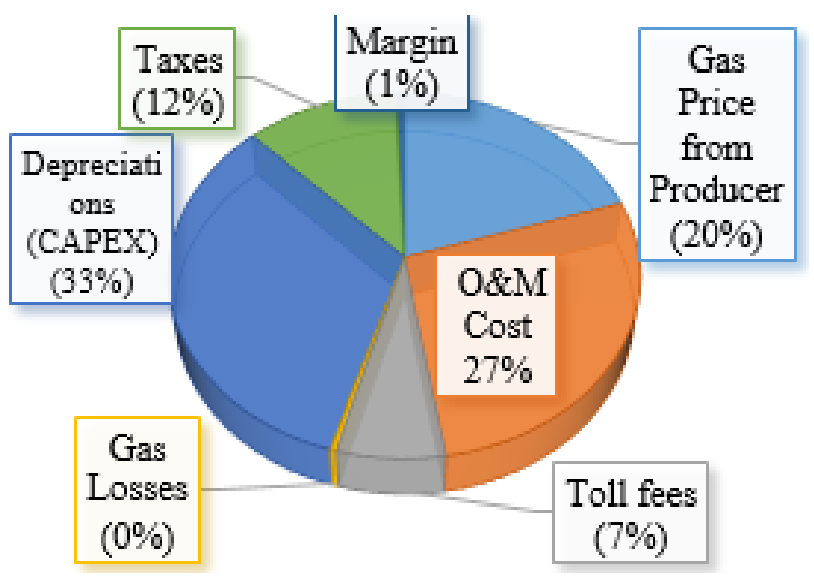

Figure 5 The components of GPs with mixed investments 50:50 from government and business entities

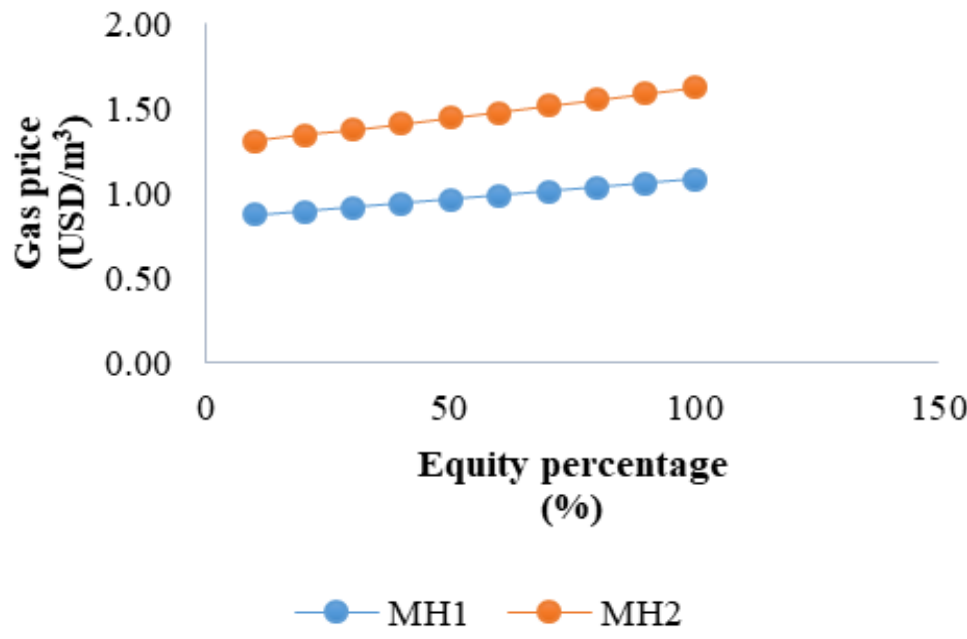

Figure 6 A comparison of household GPs with mixed invesment 50:50 on various percentages of equity, where MH1 is GPs with mixed invesment for household type $1 \mathrm{MH} 2$ is GPs for household type 2

In mixed investment scenarios, the composition of government investment can reduce the value of the total investment as a calculation of gas prices, so that gas prices will also decrease. The sensitivity of the effect of changes in gas prices due to changes in the composition of government investment in mixed investment can be seen in Figure 7. 


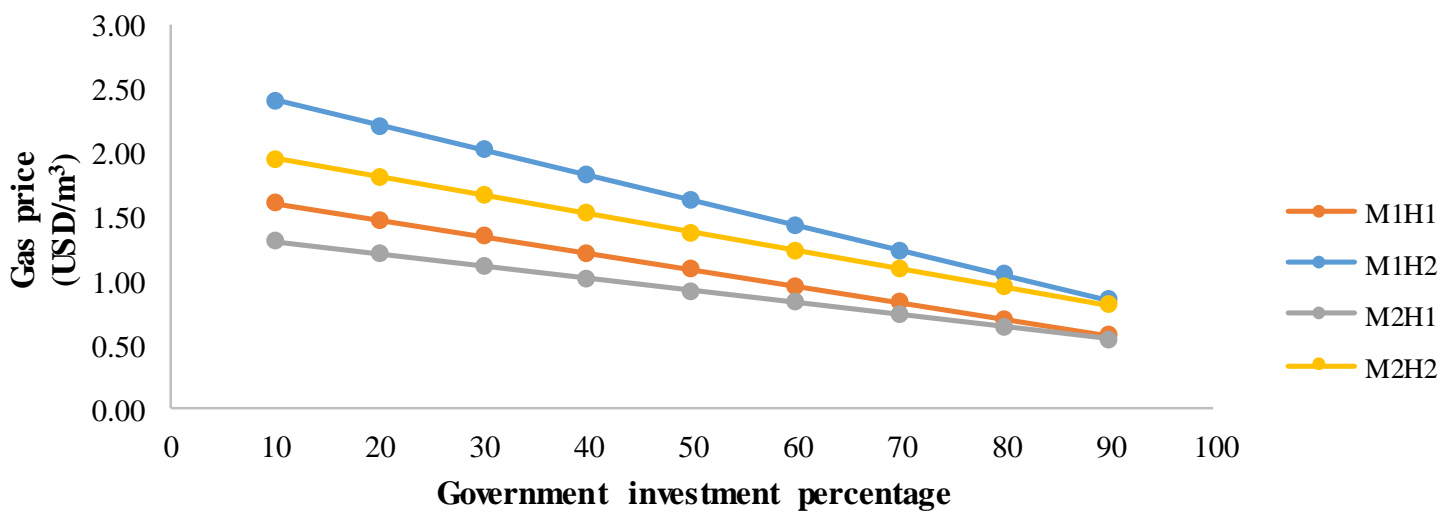

(\%)

Figure 7 The sensitivity ratios of GPs from the mixed investment scenario, where M1H1 is GPs with mixed investment for household type 1 with $100 \%$ equity, M1H2 is GPs with mixed investment for household type 2 with $100 \%$ equity, M2H1 is GPs with mixed investment for household type 1 with $70 \%$ debt and $\mathrm{M} 2 \mathrm{H} 2$ is GPs with mixed investment for household type 2 with $70 \%$ debt.

Figure 7 shows that the increasing investment composition of the government will lower the gas price. This condition is similar to the results obtained in Figure 3 and Figure 5 where the total CAPEX value decreases with increasing investment composition from the government. In chapter 2.1 it is explained that the investment derived from the government is zero. Government investment is considered an indirect subsidy from the state to the public, so it does not need to be returned through the gas price.

Based on an analysis of mixed investments, 50:50 composition of government and business entities is the best scenario. In the composition, the government accounts for half of the total investment, while the other half is borne by the business entity. With this scheme, there will be a decrease of CAPEX gas-generating price from $49 \%$ to $33 \%$ according to Figures 3 and 5. In this scenario, the government acts as a price balancer, subsidizing the public but not overly burdensome to the government budget.

Indonesia currently embraces a regulated price cost of the service system in determining household gas prices (International Gas Union, 2017). In this method, the price of gas for the household is determined by the Regulator taking into account the interests of the government, business entities and the community (The Oil and Gas Downstream Regulatory Agency of the Republic of Indonesia, 2011). If the price is high, then the state is present in the form of a subsidy, so the business entity does not lose, and the community can buy at a reasonable price.

As benchmarking, the calculation of GPs in China currently adheres to the system transformation from government pricing to government-guided pricing means that natural gas transaction price can be higher or lower than the benchmark price specified by the nation, or can be determined through negotiation but should not exceed the maximum price specified by the nation. This has removed the limit that natural gas purchase $\&$ sales contract must adopt the price fixed by the nation that has existed in China for a long time and has enhanced the price flexibility (Aolin and Qing, 2015). The selection of China as one of the benchmarking because the country embraces the same regulated price system with Indonesia where the government interferes with GPs through subsidies to reach public purchasing power (International Gas Union, 2017).

Further benchmarking is the GPs system in the countries of North America and Europe. The GPs method mainly adopts service-cost method in North America and cap pricing mechanism in Europe. (Jianglin, 2011). The price can be free to determine only if the company's capital 
returns rate not exceeds the control under service-cost method. The supervision of returns rate exists a costing mechanism that means capital spending and operating expense of investments are easy to the price of product or service unrelated to the regulated rate whose establishment is estimated by moderators after considering diverse factors comprehensively sometimes existing regulators, companies game process.

Under cap pricing mechanism, the regulators set acceptable price upper limit and companies sell goods and services at any price among the limit to retain their profits. In those liberal countries, the pricing of gas is regulated even by the Regulator, but in fact, the GPs is more disrupted by the market system (International Gas Union, 2017). The regulator only fixes the GPs by setting the upper limit of the price whose amount varies over time by the market price of gas (Jianglin, 2011). The comparison of GPs for households in some countries of the world can be seen in Figure 8 below (International Energy Agency, 2012, Aolin \& Qing, 2015).

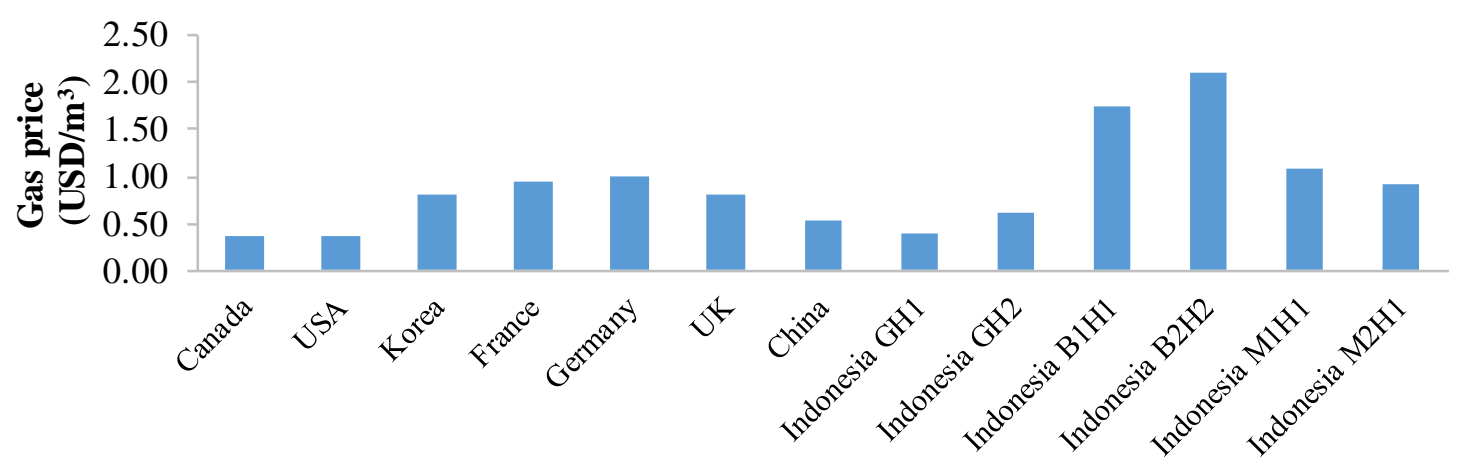

Country

Figure 8 The comparison of GPs for households in some countries of the world, where GH1 is GPs for the households type 2 with $100 \%$ government investments, GH2 is GPs for the households type 2 with $100 \%$ government investments, B1H1 is GPs for the households 1 using either $100 \%$ business entity investments with $100 \%$ equity, B2H2 is GPs for the households 1 using either $100 \%$ business entity investments with $100 \%$ with debt $70 \%$, M1H1 M1H1 is GPs with mixed invesment for household type 1 with $100 \%$ equity, and M2H2 is GPs with mixed invesment for household type 2 with $70 \%$ debt.

Based on Figure 8 it can be seen that the Indonesian GPs for households whose $100 \%$ government investment shows a low price and the same as the price of gas in China because it is both regulated and in 100\% subsidy by the government. While the GPs of the mixed investment shows similar prices to those in the European countries, since both use the market price system derived from investment between the government and business entities (International Gas union, 2017)

\section{CONCLUSION}

Investment in the development of residential gas pipeline networks can come from three sources, namely governments, enterprises (with equity and debt), and a combination of both. With the mixed investment scenario, the government can reduce subsidies without prejudice and regulate GPs so that they are affordable for the community. Moreover, the government can set and control the profit margins of the business that provides natural gas to ensure a GP that is fair and reasonable in regards to profits for the business and public welfare. Mixed investments, 50:50 composition of government and business entities is the best scenario. In the composition, the government accounts for half of the total investment, while the other half is borne by the business entity. Further research can be focused on calculating gas prices for households using the built, operate, transfer (BOT) scheme. 


\section{ACKNOWLEDGEMENT}

This research was supported by the Oil and Gas Downstream Regulatory Agency of the Republic of Indonesia, the Ministry of Energy and Mineral Resources of the Republic of Indonesia, and Universitas Indonesia.

\section{REFERENCES}

Aolin and Qing, 2015, On Natural Gas Pricing Reform in China. Journal of Natural Gas Industry, pp. 374-382

Axel, P., 2009, The Weighted Average Cost of Capital is not Quite Right: A Rejoinder. The Quarterly Review of Economics and Finance, 49(4), pp. 1481-1484

Brigham, E.F., Houston, J.F., 2009. Fundamentals of Financial Management, Eleventh Edition. Southwestern Cengage Learning, Mason, Ohio, USA, pp. 327-415

Brigham, E.F., Pettway, R.H., 1973. Capital Budgeting by Public Utilities. Financial Management, Volume 2(3), pp. 11-22

Damodaran, A., 2012. Equity Risk Premiums (ERP): Determinants, Estimation and Implications. Stern School of Business, New York, NY 10012, USA

Damodaran, A., 2013. Country Default Spreads and Risk Premiums. Stern School of Business, New York, NY 10012, USA

Federal Energy Regulatory Commission (FERC), 1999. Cost-of-Service Rates Manual. FERC, Washington, District of Columbia, USA

Gong, C., Li, L., Tian, S., Jiao, J., 2015. The Peak-Shaving Efficiency Analysis of Natural Gas Time-of-Use Pricing for Residential Consumers: Evidence from Multi-Agent Simulation. The Energy Journal, Volume 96, pp. 48-58

Hunt, P., 2014. The Weighted Average Cost of Capital for Electricity and Gas Networks: Submission on the WACC to CMA Energy Market Investigation. London, UK

International Energy Agency, 2012, Gas Pricing and Regulation, China's Challenges and IEA Experience. Paris Cedex 15, France

International Gas Union, 2017. Wholesale GP Survey-2017 Edition: A Global Review of Price Formation Mechanisms. International Gas Union, Barcelona, Spain

Jianglin, H, 2011, Comparing the Natural Gas Pipeline Pricing between Europe and America and the Revelation to China, Energy Procedia Journal, Volume 5, pp. 659-663

Lee, A., Zinaman, O., Logan, J., Bazilian, M., Arent, D., Newmark, R.L., 2012. Interactions, Complementarities and Tensions at the Nexus of Natural Gas and Renewable Energy. The Electricity Journal, Volume 25(10), pp. 38-48

Miller, R.A., 2006. The Weighted Average Cost of Capital is Not Quite Right. The Quarterly Review of Economics and Finance, Volume 49, pp. 128-138

Ministry of Energy and Mineral Resources of the Republic of Indonesia, 2013. The Book of Gas Network Development for Households in Indonesia. Ministry of Energy and Mineral Resources of the Republic of Indonesia

Ministry of Energy and Mineral Resources of the Republic of Indonesia, 2017. Reduce LPG Imports, Government Encourages Utilization of Gas Network. Press conference Number: 00107.Pers / 04 / SJI / 2017.

Moshiri, 2015. The Effects of the Energy Price Reform on Households Consumption in Iran. The Energy Policy Journal, Volume 79, pp. 177-188

Murray, Z., Frank, S., 2015. Investment and the Weighted Average Cost of Capital. How to Calculate WACC. Journal of Financial Economics, Volume 119, pp. 300-315 
Purwanto, S.W., Sommeng, A.N, 2013. The Regulation of Business Activities of Natural Gas Through Pipelines. The Oil and Gas Downstream Regulatory Agency of the Republic of Indonesia, Jakarta, Indonesia, pp. 55-102

PwC Indonesia, 2016. Indonesian Infrastructure Stable Foundations for Growth, The second edition of PwC's annual Indonesian infrastructure report, Jakarta, Indonesia

Tapia, J., 2010. The "Duty to Finance," the Cost of Capital and the Capital Structure of Regulated Utilities: Lessons from the UK. Journal of Utilities Policy, Volume 22, pp. 8-21

The Oil and Gas Downstream Regulatory Agency of the Republic of Indonesia, 2011. Rule Number 22 of 2011 Regarding the Determination of GPs for Households and Small Customers. The Oil and Gas Downstream Regulatory Agency of the Republic of Indonesia, Jakarta, Indonesia

Weijermars, R., 2011. Weighted Average Cost of Retail Gas (WACORG) Highlights Pricing Effects in The US Gas Value Chain: Do We Need Wellhead Price-Floor Regulation to Bail Out the Unconventional Gas Industry? The Energy Policy Journal, Volume 39, pp. 62916300 